\title{
今, 日本の科学技術の評価は
}

\section{技術開 発過程 の開 放}

Opening of Technology Development Processes

金出武雄

Takeo KANADE

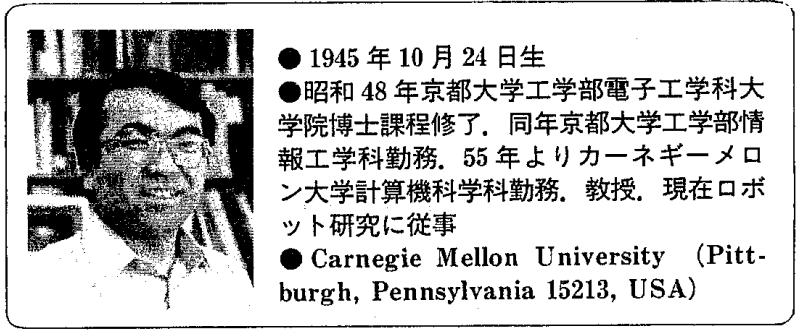

1.はじめに

私はアメリカのペンシルベニア州の西端ピッツ バーグ市にあるカーネギーメロン大学の計算機科 学科とロボット研究所に 8 年間籍を置いている. 海外に外国人として住んでいると，両方の言い分 と良い所が目と耳に入るので，アメリカ人と話す 時と日本人と話す時ではどうも立場を入れかえる ような具合になることが多い。このごろは，貿易 摩擦や技術開発競争が話題になることが多いか ら，アメリカ人に「日本社会は上下関係がきびし いから，全体が一丸となって何かをする」とか 「日本は外国にはどんどん物を売るくせに自分の 市場は閉鎖している」などと言わ机るとついつい 日本の代表のような気になって日本の弁護をす 当。一方，日本人から「アメリカは一方的だ」, 「そもそも能率が悪いのが問題だ」と聞くと，つ いついアメリカの仕組の良い所を指摘してその肩 をもっていることになる，という訳である。

今回いただいた題が「海外からみた日本の科学 技術」ということで，どうしても後者の様相が強 く，多少日本に批判がましい話になるのを扔許し いただきたい。

日本機棫等全鼓 第91第8 830 铛

\section{2. 企業化と研究のギャップ}

私自身の研究分野は人工知能・計算機による視 覚・ロボットなどである。これらの分野は日本の 科学技術は進んでおり話題になることが多い.

ところが，一般にロボット関係では「企業化実 用化において日本が一歩先んじている」という見 方がアメリカでは企業やマスコミで一般化してい るのに対し, 研究所や大学関係者の意識としては 「アメリカの方が先進的な研究をしている」とい う見方が強い，前者の方は「VLSIの市場占有 率」「ロボットの普及度」などの各種統計值やア ンケート調查にも裏づけら机たものであるのに対 し，後者の方はアメリカの研究者の目信というか 感じに近いものである。実際，日本から来ら机る 調查団の感想仍日米の研究動向を見ても，残念な がらこ机がある程度あたっているようにみえる。 しかし，企業化で進んでいて先端研究で遅机てい るということが一様にありうるだろうか，关机に してもなぜ，こういう印象が作られるのだろう か.

こういう時，「日本人は独創性に知けるが，応 用性にすぐれている」として資質とか性格とか， 日本人のカテゴリ一的要因に帰寸る向きがある。 数多くの国の人々とつき合ってみでれはないと 思う。どこの人も同じように独創的で同じ上うに
昭员相 63 年 1 月 
応用的で，それは個々人のものである。私は上記 の印象は事実半分・気分半分という所で，それは 先進的研究過程のダイナミズムという開放性（国 内・国際とも）に日米の差があるからではなかろ うかと思うのである。

\section{3. 研究プロジェクトのダイナミズム と開放性}

アメリカの科学プロジェクトは良くも悪くも大 胆でダイナミックで開放的である．私自身が関連 しているプロジェクトを例にとると，DARPA (Defense Advanced Research Project Agency) の Strategic Computing 計画という日本の第 5 世代研究に対応するプロジェクトの中の自律地上 走行車 (ALV) という部門がある。一般の地形 をセンサを使って高速に走行するロボットを作る というプロジェクトがスタートした 1984 年段階 でも現在でもかなり大胆な計画である。また，今 年から始まった NASAの火星探査ロボットも楽 しい. 1998 年〜2003 年に打上げる火星の石や砂 を地球に持ち帰るミッションのために火星の表面 を走りまわってサンプル採取するロボットを開発 するというものである。こ机らのプロジェクトは 大規模なものにもかかわらず極めて短い期間に立 案さ机実施に移された。もちろん，さめた見方を す机ば「軍事利用」「国家威信」といったものに よって正当付けされていると言えなくもないが， こういうプロジェクトを大規模に大学・企業が共 同的・競争的に進めている所にアメリカのダイナ ミズムがある。

プロジェクトへの参加は企業，大学を問わず， 提案書の提出と評価によって競争的に行わ机る. 研究結果の公表も秘密研究でないからまったく自 由である。外国の視察団にも完全に公開されてい るし，そもそも，私のような外国人が研究代表者 としてやっていけること自体警きと言える。

このように開放的な理由のひとつに，プロジェ クトの推進に大学が大きな役割をはたしている点 があると思う. Strategic Computing 計画の計算 機視覚関係では基礎部閒において 15 の研究契約 のうち 70\%が大学で，応用部門を含めても30\% 资占める。大学は企業上違って基本的に開放的で
あるという特徵がある. 現在の技術的制限にとら わ机なで自由に考えることが許さ机る，新しい ことをやるのが目的だから現存の良い技術はどこ から取り入机ても苦にも失点にもならない。新し

く考えたことをどんどん外に出したがるから訪問 者にも自由に見せるし，論文にも書く．秘密研究 はしないから，いい人であれば国籍を気にしない で雇うことができる。こ机らの総合的結果とし て, 研究プロジェクトの進展過程が国際レベルで よく見えるということになる。

\section{4. 日本のプロジェクトの開放度}

翻って日本の開放度はどうか. 新世代コンピュ 一夕，極限作業ロボット，翻訳電話などは我々の 分野で世界的に注目度の高い日本のプロジェクト と言える。しかし，残念ながらそれらの技術的進 展状況のニュースはアメリカ人研究者に十分には 流れて来ていない．これには日本語が読めるアメ リカ人が少ないという言葉の障壁も大きいが，そ もそもこ机らのプロジェクトが企業や企業組合が 中心となっていて, 直接研究の推進に国際的な研 究者や大学といった開放的な組織が携っている度 合が少ないことと関係あるのではないか，企業で は，ランダムな客員研究員を受け入机ることはし ないし，研究開発の過程はできるだけふせるとい う当然の戦略をとるからである。

更に，日本で何かおもしろい技術を開発する時 に，ことさら「日本独自」ということを強調しす ぎるのも開放的にする点からみて逆効果のように 思う。アメリカで「アメリカ独自」という形容を 技術につけることはめったにない，例えば，人工 知能について「論理的にしか思考出来ない西洋思 想のもとには育たない。いまいを理解する東洋 思想のもとでこそ発達する」とか「日本語のみで 考只ら机た日の丸OS」というのはスローガンと して㧍もしろいけれど，だから良い技術なのだと いう議論には結びつけら机ないと思うのである。 日本人には独創性がないという評判（私に言才せ れば神話）在打ち消すため無理に独自性を強調す る努力の上うに思える。独自性が日本人・日本語 であることから生ま机るとすると結果的にますま 寸研究過程に外国人が入ること定難しくする。 


\section{5. 技術開放の今後へ向けて}

最近，貿易収支の不均衡問題に関連して，市場 の開放・国際化ということが日本で叫ばれてい る。技術大国である日本として更に一歩踏み込ん で，技術開発過程の開放・国際化を進めるべきで はあるまいか。この点に開し，日本でポジティブ な動きが出はじめている，私の知っている範囲で も，ICOTにはNSF との滞在研究員の制度があ るし，日本の企業で柱国際的に開かれた研究所作 りが盛んらしい，この場合すでに著名な大家を招 いて意見をきくというだけでなく，若手の研究者 の交流をはかって実質的な研究開発過程の開放を 目ざすのが重要である。アメリカの大学には日本 の企業・大学から極めて多数の若手客員研究者が 来ている. わ机わ机カーネギーメロン大学の計算 機学科とロボット研究所だけをとっても，約 20 人以上の日本人研究者が滞在している.日本の大 学にも代表的プロジェクトを開放して客員で来る ことを魅力的にす机ば良い.アメリカの技術系大
学院生の日本への関心は高い. 私の学部の若手音 声研究者で日本の研究プロジェクトで働いている 人も知っているし，私の学生ですでに日本企業で 夏休みの間 Summer Jobとして働いて好評だっ た者，学位取得後 2 年程日本で働きたいという者 もいる位である．先日もある日本企業が研究者募 集のパンフレットを残していったら，あっという 間に売り切れてしまった。ただ，現在の所，日本 での研究歷がその人の経歷にどうプラスに評価さ れるかという点がはっきりしない問題があるから 実際に行ってみようという人は今の所多くない. しかし，これは䳕と卵の問題で，有能な人が日本 の技術開発過程に参加し良い仕事をす机ば，日本 で働くことが経歴としてプラスに評価されるよう になり，更に希望者が増えるという好循環を生む ことを期待したい.

技術開発過程の開放が進めば「害用化」と「先 進的研究」の間のイメージのギャップも埋まるは ずである。

（原稿受付 昭和 62 年 12 月 2 日） 